\title{
GMR
}

\section{Study of genetic variability in pigs after the traditional breeding program}

\author{
I.M. Ferreira ${ }^{1}$, G.S. Vieira ${ }^{2}$, T.F. Braga ${ }^{1}$, T.C.F. Silva ${ }^{1}$, M.M. Franco ${ }^{3,4}$ and \\ R.C. Antunes ${ }^{4}$ \\ ${ }^{1}$ Programa de Pós-Graduação em Ciências Veterinárias \\ ${ }^{2}$ Laboratório de Genética - Medgen, Uberlândia, MG, Brasil \\ ${ }^{3}$ Embrapa - Recursos Genéticos e Biotecnologia, \\ Laboratório de Genética Molecular Animal, Brasília, DF, Brasil \\ ${ }^{4}$ Universidade Federal de Uberlândia, Uberlândia, MG, Brasil \\ Corresponding author: I.M. Ferreira \\ E-mail: isaura@iftm.edu.br \\ Genet. Mol. Res. 16 (3): gmr16039759 \\ Received June 23, 2017 \\ Accepted August 22, 2017 \\ Published September 21, 2017 \\ DOI http://dx.doi.org/10.4238/gmr16039759
}

Copyright $(2017$ The Authors. This is an open-access article distributed under the terms of the Creative Commons Attribution ShareAlike (CC BY-SA) 4.0 License.

\begin{abstract}
Molecular markers are tools used to improve genetic gains. The objective of this study was to analyze the security of alleles of molecular marker genes for characteristics of economic interest in a pure population of pigs. After the extraction of DNA from the hair of 272 Large White matrices, the allele and genotype frequency of single nucleotide polymorphism was performed using the ARMSPCR Multiplex technique in the DGAT1, LEPR, H-FABP, MC4R, and SREBF1 genes using RFLP-PCR for the GH gene. After capillary electrophoresis in an automated DNA sequencing of the DGAT1, LEPR, H-FABP, and SREBF1 genes, no polymorphisms were found. Only the MC4R marker presented $100 \%$ heterozygosity. For the GH gene, 209 of the initial population samples were genotyped. The PCR product (605 bp) was digested with the restriction enzyme DdeI, with fragments being of 335,148 , and $122 \mathrm{bp}$ for the $\mathrm{D}_{1}$ allele and 457 and $148 \mathrm{bp}$ for the $\mathrm{D}_{2}$ allele. The genotypic frequency obtained of $\mathrm{D}_{1} \mathrm{D}_{2}$ was
\end{abstract}

Genetics and Molecular Research 16 (3): gmr16039759 
$88 \%$ and of $\mathrm{D}_{2} \mathrm{D}_{2}$ was $22 \%$. The $\mathrm{D}_{1}$ allele presented a frequency of $11 \%$ and the $\mathrm{D}_{2}$ allele of $89 \%$. The high intensity of selection for commercial breeds justifies the absence or the low number of polymorphisms for the genes studied.

Key words: DNA; SNPs; Polymorphism; Molecular markers; Gene-assisted selection

\section{INTRODUCTION}

The use of candidate genes related to economic interest traits such as markers has been widely applied in genetic breeding programs (Rotschild, 2000; Chen et al., 2007; Coutinho et al., 2010). However, the increase in these contributions is restricted when one is dealing with characteristics of low heritability or those that are difficult to measure, for example, carcass yield, disease resistance, longevity, gender/sex-related, or in the case of phenotypes that are difficult to measure (Dekkers, 2004; Goddard and Hayes, 2009; Coutinho et al., 2010).

According to Hayashi et al. (2004) and Faleiro (2007), single nucleotide polymorphisms (SNPs) come about by mutation in a single-base pair in the DNA sequence between members of the same species that can cause phenotypic differences. The advantages of SNPs as genetic markers are the availability of genotype protocols, which are fast, reliable, and reproducible, with high-performance or high-density protocols and substantially lower costs (Lenstra et al., 2012). These marker genes are potential candidates due to their important physiological effects related to characteristics of economic importance (Franco et al., 2005). This information can be incorporated into traditional breeding methods (Li et al., 2006; Bižiené et al., 2011).

Among the molecular markers associated with characteristics of economic interest are the genes, among which we can mention: DGAT1 (diacylglycerol acyltransferase 1), a gene that encodes the enzyme of the same name acting in the metabolism of intestinal fat absorption, lipoprotein synthesis, adipose tissue formation, and lactation (Nonneman and Rohrer, 2002; Cui et al., 2011); LEP (leptin) and LEPR (leptin receptor) are important regulators of appetite, metabolism, reproduction (Wylie, 2011; Georgescu et al., 2014), and the deposition of intramuscular fat (Tyra and Ropka-Molik, 2011); H-FABP (heart-type fatty acid binding protein) is related to the regulation of fatty acid uptake and intracellular transport (Gerbens et al., 1999; Tyra et al., 2011; Chao et al., 2012); MC4R (melanocortin 4 receptor gene) is an important genetic marker for characteristics related to backfat thickness, feed intake, and growth rate (Jokubka et al., 2006; Óvilo et al., 2006); SREBF1 (sterol regulatory element binding transcription factor) involved in the differentiation of adipocytes, as well as cholesterol and fatty acids (Stachowiak et al., 2013); and GH (growth hormone) that influences economically important characteristics such as carcass weight and fat thickness (Franco et al., 2003; Bižienè et al., 2011).

All the genes mentioned above are involved in the process of lipid metabolism and growth. The lipids are involved in the production of steroid hormones and are also important signaling molecules involved in the regulatory mechanisms of maturation and, therefore, in the acquisition of oocyte competence (Prates et al., 2014). Therefore, they may be related to reproductive characteristics.

In this way, the objective of this study was to analyze in a pure population of Large White pigs, which is under selection effect for the amount of meat in the carcass, backfat

Genetics and Molecular Research 16 (3): gmr16039759 
thickness, age and weight at slaughter, number of piglets weaned per sow/year, and the allelic and genotypic frequencies of the genes DEGAT1, LEPR, H-FABP, MC4R, SREBF1, and GH.

\section{MATERIAL AND METHODS}

The hair samples were collected from animals coming from a breeding/improvement program in the final phase of genetic stabilization. Mutations (SNPs) were used in genes associated with lipid metabolism available in GenBank, but with no or only a very few polymorphism studies.

\section{DNA extraction}

Two hundred and seventy-two (272) females were used in this research for the genes H-FABP, DGAT1, LEPR, MC4R, and SREBF1, and of these, 209 for the GH gene. To extract the DNA from each sow, 10 hairs with bulbs were used, and the procedure was carried out according to the protocol adapted from Miller et al. (1988).

\section{DNA amplification}

DNA amplification was carried out using ARMS (amplification-refractory mutation system) by PCR (polymerase chain reaction) multiplex of 5 genes with M13 tail tagged (Table 1).

PCRs were carried out using $20 \mathrm{ng}$ DNA, $1 \mathrm{X}$ buffer [200 $\mu \mathrm{M}$ dNTP, $2.5 \mathrm{mM} \mathrm{MgCl}_{2}$, $2 \mathrm{U}$ Taq DNA polymerase, $4 \mathrm{pmol}$ of each primer (Table 1), 20 pmol of each probe M13-FAM and M13-NED] and the volume adjusted to $20 \mu \mathrm{L}$ with ultrapure water. All reagents, except the primers and probes, were from Invitrogen ${ }^{\circledR}$.

Three primers were designed for each of the genes using the sequences deposited in GenBank. They were designed using the Primer3 (http://frodo.wi.mit.edu/edu/primer3/) program, and their quality was verified using Oligo Analyzer 3.1 (http://www.idtdna.com/ calc/analyzer).

\begin{tabular}{|c|c|c|c|}
\hline Gene & Primer & Amplicon (bp) & GenBank No. \\
\hline \multirow[t]{3}{*}{ DGAT1 } & F*: 5'-M13-1**AGC CAG CGC CCC CGG TCC-3' & & XM_005655311.2 \\
\hline & F*: 5'-M13-2**-AGC CAG CGC CCC CGG TCT-3' & 143 & $1680(\mathrm{C} / \mathrm{T})$ \\
\hline & $\mathrm{R}^{*}:$ 5'-CTG TGC CTG CCT GCC ATC-3' $^{\prime}$ & & \\
\hline \multirow[t]{3}{*}{ LEPR } & F: 5'-GTG ATA ACT GCA TTT GAC TTG GC-3' & & \\
\hline & R: 5'-M13-1 AGT TTG ATA AGT AGG TAC CAC TTA T-3' & 209 & GQ268934 \\
\hline & R: 5'-M13-2 AGT TTG ATA AGT AGG TAC CAC TTG A-3' & & $228(\mathrm{~A} / \mathrm{G}) ; 229(\mathrm{~T} / \mathrm{A})$ \\
\hline \multirow[t]{3}{*}{ H-FABP } & F: 5'-M13-1- CTA GCC CAG CCT CAC CAT GGT-3' & & \\
\hline & F: 5'-M13-2 CTA GCC CAG CCT CAC CAT GGC-3' & 183 & JN646857 \\
\hline & R: 5'-TGA GTC CCC ATT CAC TTC GAT G-3' & & $48(\mathrm{C} / \mathrm{T})$ \\
\hline \multirow[t]{3}{*}{ MC4R } & F: 5'-TAC CCT GAC CAT CTT GAT TG-3' & & \\
\hline & R: 5'-M13-2 GAG TGC ATA AAT CAG GGG ATC-3' & 196 & NM_214173.1 \\
\hline & R: 5'-M13-1 GAG TGC ATA AAT CAG GGG ATT-3' & & $1425(\mathrm{~T} / \mathrm{C})$ \\
\hline \multirow[t]{3}{*}{ SREBP1 } & R: 5'-M13-2 CAG CAC ACG CGC CTC CAC GA-3' & & \\
\hline & R: 5'-M13-1 CAG CAC ACG CGC CTC CAT GG-3' & 263 & AB686492.1 \\
\hline & F: 5'-GCC GTG GTG AGA AGC GGA CGG CTC AC-3' & & 13334(G/A) \\
\hline
\end{tabular}

*F: forward; R*: reverse; **M13-1 5'-FAM-GTC AAG ATG CTA CCG TTC, **M13-2 5'-NED-5'-ACT CAT CGG AAT CGT ATG.

Genetics and Molecular Research 16 (3): gmr16039759 
The amplification of the DNA was carried out in a thermocycler (Thermal Applied BioSystems ${ }^{\circledR}$ Cycler 2720), under the following conditions: $95^{\circ} \mathrm{C}$ for $10 \mathrm{~min}, 5$ cycles of $95^{\circ} \mathrm{C}$ for $15 \mathrm{~s}, 55^{\circ} \mathrm{C}$ for $45 \mathrm{~s}, 70^{\circ} \mathrm{C}$ for $1 \mathrm{~min}$ and $56 \mathrm{~s}, 31$ cycles at $95^{\circ} \mathrm{C}$ for $15 \mathrm{~s}, 53^{\circ} \mathrm{C}$ for $45 \mathrm{~s}$, $70^{\circ} \mathrm{C}$ for $1 \mathrm{~min}$, a half and extension at $70^{\circ} \mathrm{C}$ for $30 \mathrm{~s}$, and a final extension at $25^{\circ} \mathrm{C}$ for $10 \mathrm{~min}$.

\section{Genotyping using capillary electrophoresis}

For capillary electrophoresis genotyping, $1 \mu \mathrm{L}$ of the PCR product plus $9 \mu \mathrm{L}$ Formamide Hi-Di ${ }^{\mathrm{TM}}$ (Applied Biosystems) and $0.3 \mu \mathrm{L}$ of the LIZ 600 (Applied Biosystems) marker were used. The reactions were carried out in a thermocycler (Thermal Applied BioSystems ${ }^{\circledR}$ Cycler 2720) at $95^{\circ} \mathrm{C}$ for $7 \mathrm{~min}$ for denaturation. Then, the samples were subjected to capillary electrophoresis on the ABI 3130 sequencer (Applied Biosystems), and the fragments were analyzed using the GeneMapper 3.0 software.

From the results of ARMS-PCR multiplex for DGAT1, LEPR, H-FABP, MC4R, and SREBF1 genes the polymorphisms were identified by the presence of a different color peak for each homozygote in each gene and two different color peaks in the electropherogram in heterozygous individuals.

\section{PCR-RFLP}

PCR-RFLP was carried out for the GH gene using $1 \mathrm{X}$ buffer $\left[2 \mathrm{mM} \mathrm{MgCl}_{2}, 0.4 \mathrm{mM}\right.$ $\mathrm{dNTP}, 10 \mathrm{pmol}$ of each primer (forward and reverse), $1 \mathrm{U}$ Taq polymerase, $1 \mu \mathrm{L}$ genomic DNA], and ultrapure water to a final volume of $20 \mu \mathrm{L}$. The sequence, amplicon, and GenBank registration number of the primers used are in Table 2.

Table 2. Primers designed to amplify target regions of the GH gene.
\begin{tabular}{|l|c|c|c}
\hline Gene & *Primer & Amplicon (bp) & GenBank No. \\
\hline GH & F: $5^{\prime}$-TTATCCATTAGCACATGCCTGCCAG-3' & 605 & M17704 \\
\cline { 2 - 4 } & R: '-CTGGGGAGCTTACAAACTCCTT-3' $^{\prime}$ & & \\
\hline * Primer designed by Larsen and Nielsen (1993), from the sequence of Vize and Wells (1987). F* forward; R.
\end{tabular}

*Primer designed by Larsen and Nielsen (1993), from the sequence of Vize and Wells (1987). F: forward; R: reverse.

The reactions were carried out in a thermocycler $\left(\mathrm{T} 100^{\mathrm{TM}} \mathrm{Thermal}\right.$ Cycler) under the following conditions: $95^{\circ} \mathrm{C}$ for $3 \mathrm{~min}, 35$ cycles at $95^{\circ} \mathrm{C}$ for $45 \mathrm{~s}, 60^{\circ} \mathrm{C}$ for $40 \mathrm{~s}, 76^{\circ} \mathrm{C}$ for 1 $\mathrm{min}$, and a final extension at $76^{\circ} \mathrm{C}$ for $4 \mathrm{~min}$. After the amplification $5 \mu \mathrm{L}$ of the PCR product was applied to an agarose gel at $2 \%$.

The remainder of the amplification was digested with $1 \mathrm{U}$ of the DdeI (Promega) enzyme and incubated for $16 \mathrm{~h}$ at $37^{\circ} \mathrm{C}$, and then the product was applied to an agarose gel at $2.5 \%$. For the GH gene after digestion of the samples, two alleles were obtained: $\mathrm{D}_{1}$ with fragments of 335,148 , and $122 \mathrm{bp}$ and $\mathrm{D}_{2}$ with 457 and $148 \mathrm{bp}$.

\section{RESULTS}

For the DGAT1 gene, the frequency of the C allele and the CC genotype was $100 \%$ in the population. LEPR and H-FABP presented a $100 \%$ frequency of GAGA and TT genotypes and $100 \%$ of GA and $\mathrm{T}$ alleles, respectively. In the MC4R gene, $100 \%$ of the genotype

Genetics and Molecular Research 16 (3): gmr16039759 
frequency (TC) and 50\% of the frequency of each allele ( $\mathrm{T}$ and $\mathrm{C}$ ) were observed. Concerning the SREBF1 gene, $100 \%$ of genotypic and allelic frequencies were also found (AA and A, respectively). GH presented $22 \%$ of the $\mathrm{D}_{1} \mathrm{D}$ genotype and $78 \%$ of the $\mathrm{D}_{2} \mathrm{D}_{2}$, with an $11 \%$ frequency of $\mathrm{D}_{1}$ allele and $89 \%$ of $\mathrm{D}_{2}$ (according to Table 3 ).

For the amplification reaction of the GH gene, a 605-bp amplicon was obtained (Figure 1). After digestion with the DdeI enzyme, 457-, 335-, and 148-bp fragments were observed (Figure 2). It was not possible to visualize fragment 122.

Table 3. Genotype and allelic frequencies of DGAT1, LEPR, H-FABP, MC4R, SREBF1, and GH genes in Large White breeders.

\begin{tabular}{|c|c|c|c|c|}
\hline Genes & Genotype & Genotype frequency $(\%)$ & Alele & Allele frequency (\%) \\
\hline \multirow[t]{3}{*}{ DGAT1 } & TT & 0 & $T$ & 0 \\
\hline & $\mathrm{TC}$ & 0 & $\mathrm{C}$ & 100 \\
\hline & $\mathrm{CC}$ & 100 & & \\
\hline \multirow[t]{3}{*}{ LEPR } & GAGA & 100 & GA & 100 \\
\hline & GAAT & 0 & AT & 0 \\
\hline & ATAT & 0 & & \\
\hline \multirow[t]{3}{*}{ H-FABP } & TT & 0 & & \\
\hline & TC & 0 & $\mathrm{~T}$ & 0 \\
\hline & $\mathrm{CC}$ & 100 & $\mathrm{C}$ & 100 \\
\hline \multirow[t]{3}{*}{ MC4R } & TT & 0 & & \\
\hline & TC & 100 & $\mathrm{~T}$ & 50 \\
\hline & $\mathrm{CC}$ & 0 & $\mathrm{C}$ & 50 \\
\hline \multirow[t]{3}{*}{ SREBF1 } & GG & 0 & $\mathrm{G}$ & 0 \\
\hline & GA & 0 & A & 100 \\
\hline & AA & 100 & & \\
\hline \multirow[t]{3}{*}{ GH } & $\mathrm{D}_{1} \mathrm{D}_{1}$ & 0 & 0 & 0 \\
\hline & $\mathrm{D}_{1} \mathrm{D}_{2}$ & 22 & $D_{1}$ & 11 \\
\hline & $\mathrm{D}_{2} \mathrm{D}_{2}$ & 78 & $\mathrm{D}_{2}$ & 89 \\
\hline
\end{tabular}

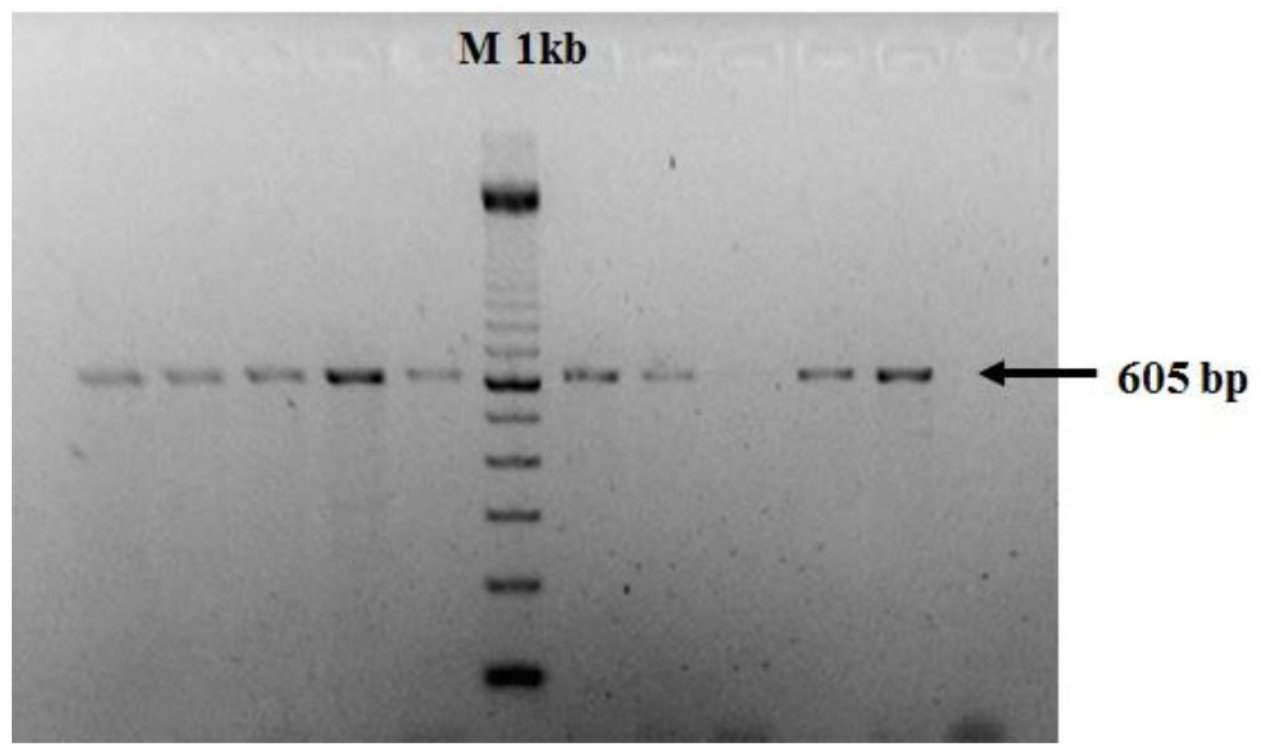

Figure 1. Amplification of the GH gene on 2\% agarose gel showing an amplicon of $605 \mathrm{bp}$ and the marker (M) of $1 \mathrm{~kb}$.

Genetics and Molecular Research 16 (3): gmr16039759 


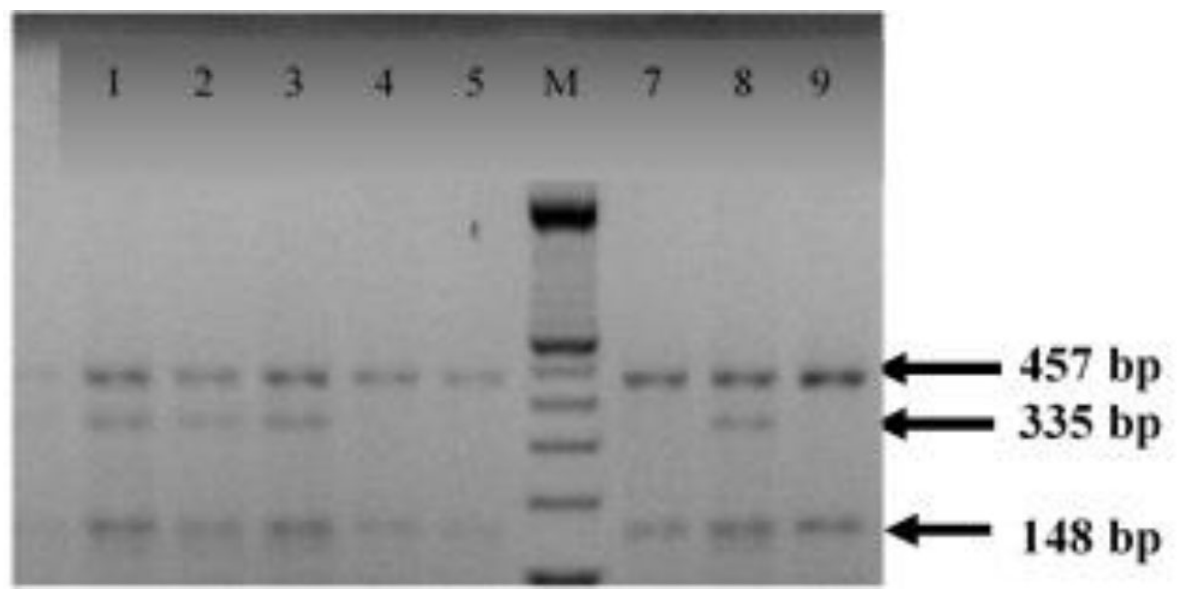

Figure 2. GH gene digested by $D d e l$ enzyme on $2.5 \%$ agarose gel. Lane $M=1-\mathrm{kb}$ marker; lanes $1,2,3$, and $8=$ fragments 457,335 , and $148\left(\mathrm{D}_{1} \mathrm{D}_{2}\right)$ and lanes $4,5,7$, and $9=$ showing fragments 457 and $148\left(\mathrm{D}_{2} \mathrm{D}_{2}\right)$.

\section{DISCUSSION}

The results found for the DGAT1, LEPR, H-FABP, and SREBF1 genes showed that they reached the fixation of their alleles, indicating the absence of genetic variation. This may be justified by the high selection pressure experienced by the animals over several years. Besides, selection for other traits or characteristics may have indirectly generated a decrease in the genetic variability of the population (Ayres et al., 2006).

Gondim (2015) when working with the DGAT1 gene in distinct populations (Large White $\mathrm{x}$ Landrace, Piau, Large White $\mathrm{x}$ Landrace, Jiaxing x Meishan) concluded that the C allele is practically fixed in these populations meaning that they are in a pronounced selection process, since they were animals from nucleus and multiplier farms. Zang et al. (2016), when working with the same gene but with a deletion in the 3'-UTR region, determined the existence of an allelic dominance. In the present study, the $\mathrm{C}$ allele presented itself as homozygous for all individuals analyzed (Table 3 ).

In regards to the LEPR gene, the findings of this study corroborate with Gondim (2015) who did not find any variation in the genotypes in the studied populations. According to the same author, the allelic frequencies in a finite population stem or derive from fixation or exclusion by decreasing the heterozygosity of the population. Balatsky et al. (2016), when working with a different SNP but in the same gene, found three genotypes (CC, CT, and TT), with the $\mathrm{C}$ allele having a $66 \%$ frequency.

For the H-FABP gene, a $100 \%$ homozygous for the TT genotype was found, contradicting or disagreeing with the results found by Gondim (2015), where the highest frequency was reported for the CC genotype. Gondim (2015) also reported that SNPg.240T >C when homozygous for the $\mathrm{T}$ allele decreases the first period of coverage, and the delivery/ parturition interval, showing that the result of the population studied in this experiment reached the apex for selection. Chen et al. (2014) analyzed the H-FABP polymorphisms using PCR-RFLP using 3 restriction enzymes in six swine breeds and as the results of this study found a high predominance of one allele in at least $50 \%$ of the analyzed loci. Li et al. (2006),

Genetics and Molecular Research 16 (3): gmr16039759 
when studying which would be the best markers for native Chinese breeds that would help in selection and conservation, showed significant differences in the frequencies of genotypes and alleles between breeds. When using the PCR-RFLP, a frequency of $100 \%$ of the AA genotype was found for the Meishan breed.

The only marker found in this study in heterozygosis was MC4R, which indicates that there are at least two distinct pure lineages for the formation of this population, as each one contributed with identical alleles. Gondim (2015) observed a greater frequency of the T allele regarding the $\mathrm{C}$ allele for the three genetic groups evaluated. The TT genotype of Piau and LWLD had a frequency of 52 and $45 \%$, respectively; however, the LLJM gene group had a higher genotypic frequency of the heterozygous CT (49\%). Li et al. (2006), using another polymorphic region of the 6 breeds studied, found $100 \%$ of homozygous BB in the Meishan breed. A study performed by Óvilo et al. (2006) in commercial hybrid pigs (Landrace x Taihu $x$ Large-White) found two polymorphisms of the MC4R gene and the AA, AG, and GG genotypes with the following frequencies 8,36 , and $56 \%$, respectively, and observed that none of the alleles would have a clear advantage in selection processes.

Chen et al. (2008) carried out experiments to clarify the role of SREBF1 in the deposition of intramuscular fat (IMF) in crossbred Erhualian x Duroc animals, called Sutai. They found three AA genotypes with a frequency of $50 \%$, AB (36\%), and BB (14\%). The authors also correlated that both the level of mRNA in SREBF1 and IMF in the muscles were greater in the $\mathrm{AB}$ and $\mathrm{BB}$ genotypes than in $\mathrm{AA}$ animals. With these results, they suggest that the SNP of the SREBF1 gene could be used as a genetic marker to improve the IMF in swine. Renaville et al. (2010,2013), when studying swine populations using the same SNP as studied here, found the allele A with a frequency of 76 and $74.45 \%$, whereas in the population studied here $100 \%$ of the allele A was observed (Table 3 ).

Franco et al. (2005) found the genotype frequencies of 0.662 for the $D_{1} D_{1}$ genotype and 0.338 for the $\mathrm{D}_{1} \mathrm{D}_{2}$ genotype and the allelic frequencies of 0.831 for $\mathrm{D}_{1}$ and 0.169 for $\mathrm{D}_{2}$ for the GH gene in a Landrace population, differing from the latter study with the Large White population, in which the $\mathrm{D}_{1} \mathrm{D}_{1}$ allele was not found. The referred authors considered that the animals with the $\mathrm{D}_{1} \mathrm{D}_{2}$ genotype had a lower fat thickness and a greater average daily gain of weight. The possible explanation for the result could be that this polymorphism leads to an amino acid alteration in the protein sequence, thereby interfering with the efficiency or amount of GH secretion.

In the study carried out by Franco et al. (2001) with 3 swine populations (Pietran, Large White, and Landrace), two polymorphisms (GHD with the enzyme DdeI and GHC with enzyme $H h a I$ ) were found. Large White GHD genotypes showed a greater number of individual heterozygous as well as an increase in heterozygotes for the GHC polymorphism in the Landrace and Pietran breeds. The phenotypic frequencies may be influenced by the selection for reproductive and performance characteristics as against the halothane gene according to the authors. Although no high genetic variability was obtained, the markers can be used in genetic studies of populations under lower selection pressure (Franco et al., 2001).

In general, world literature has shown that even when using different populations and/ or different genetic markers with diverse polymorphism identification techniques, it is often the determination of high allelic predominance, as was observed in most of the genes studied here, that holds true (Franco et al., 2001; Li et al., 2006; Bosse et al., 2012; Renaville et al., 2010, 2013).

This leads to the confirmation that the traditional improvements and selection

Genetics and Molecular Research 16 (3): gmr16039759 
processes of superior genotypes throughout the domestication process led to the fixing of genes of interest and consequently other related genes, reducing genetic variability and demanding more efficient programs in the selection of the best genotypes and in the preservation of the genome bank, so that in the future it will be possible to introduce new genotypes and recover genetic diversity. Every day the need for the use of molecular markers is becoming more evident, whether it is to help in assisted breeding programs or genetic analyses and the determination of population inbreeding (Herrero-Medrano et al., 2014; Schiavo et al., 2016; Peripolli et al., 2017).

\section{CONCLUSION}

In general, low polymorphism was found in the GH gene, and no polymorphisms were found in the other genes, which indicate the good efficiency in generating homozygous animals in traditional breeding programs.

\section{Conflicts of interest}

The authors declare no conflict of interest.

\section{ACKNOWLEDGMENTS}

The authors thank Embrapa Genetic Resources \& Biotechnology.

\section{REFERENCES}

Ayres DR, Albuquerque LG, Costa RB, Laureano MMM, et al. (2006). Polimorfismos no gene da Leptina relacionados com escores visuais de conformação, precocidade e musculatura de bovinos da raça Nelore. In: XVIII Congresso de Iniciação Científica da UNESP, 2006, Jaboticabal. Anais do XVIII Congresso de Iniciação Científica da UNESP, Jaboticabal.

Balatsky V, Bankovska I, Pena RN, Saienko A, et al. (2016). Polymorphisms of the porcine cathepsins, growth hormonereleasing hormone and leptin receptor genes and their association with meat quality traits in Ukrainian Large White breed. Mol. Biol. Rep. 43: 517-526. https://doi.org/10.1007/s11033-016-3977-z

Bižienė R, Miceikienė I, Baltrėnaitė L and Krasnopiorova N (2011). Association between growth hormone gene polymorphism and economic traits in pigs. Vet. Med. Zoot. 56: 2731.

Bosse M, Megens H-J, Madsen O, Paudel Y, et al. (2012). Regions of homozygosity in the porcine genome: consequence of demography and the recombination landscape. PLoS Genet. 8: e1003100. https://doi.org/10.1371/journal. pgen. 1003100

Chao Z, Wang F, Deng CY, Wei LM, et al. (2012). Distribution and linkage disequilibrium analysis of polymorphisms of MC4R, LEP, H-FABP genes in the different populations of pigs, associated with economic traits in DIV2 line. Mol. Biol. Rep. 39: 6329-6335. https://doi.org/10.1007/s11033-012-1454-x

Chen J, Yang XJ, Xia D, Chen J, et al. (2008). Sterol regulatory element binding transcription factor 1 expression and genetic polymorphism significantly affect intramuscular fat deposition in the longissimus muscle of Erhualian and Sutai pigs. J. Anim. Sci. 86: 57-63. https://doi.org/10.2527/jas.2007-0066

Chen JN, Jiang YZ, Cen WM, Xing SH, et al. (2014). Distribution of H-FABP and ACSL4 gene polymorphisms and their associations with intramuscular fat content and backfat thickness in different pig populations. Genet. Mol. Res. 13: 6759-6772. https://doi.org/10.4238/2014.August.28.20

Chen K, Baxter T, Muir WM, Groenen MA, et al. (2007). Genetic resources, genome mapping and evolutionary genomics of the pig (Sus scrofa). Int. J. Biol. Sci. 3: 153-165. https://doi.org/10.7150/ijbs.3.153

Coutinho L, Rosário MF, Jorge EC, Biotecnologia Animal (2010). Estud. Av. 24:70. https://doi.org/10.1590/S0103$\underline{40142010000300009}$

Genetics and Molecular Research 16 (3): gmr16039759 
Cui JX, Zeng YQ, Wang H, Chen W, et al. (2011). The effects of DGAT1 and DGAT2 mRNA expression on fat deposition in fatty and lean breeds of pig. Livest. Sci. 140: 292-296. https://doi.org/10.1016/j.livsci.2011.04.007

Dekkers JCM (2004). Commercial application of marker- and gene-assisted selection in livestock: strategies and lessons. J. Anim. Sci. 82 E-Suppl (Suppl): E313-E328.

Faleiro FG (2007). Marcadores genéticos-moleculares aplicados a programas de conservação e uso de recursos genéticos. Embrapa, Planaltina, 102.

Franco MM, Santana BAA, Goulart LR, Antunes RC, et al. (2001). Determination of polymorphisms in the growth of the hormone gene in three populations of pigs. Cienc. Rural 3: 329-331. https://doi.org/10.1590/S0103$\underline{84782001000200023}$

Franco MM, Almeida JF, Souza GRL, Antunes RC, et al. (2003). Development of a quantitative competitive reverse transcriptase polymerase chain reaction for the quantification of growth hormone gene expression in pigs. Genet. Mol. Biol. 26: 13-18. https://doi.org/10.1590/S1415-47572003000100003

Franco MM, Antunes RC, Silva HD and Goulart LR (2005). Association of PIT1, GH and GHRH polymorphisms with performance and carcass traits in Landrace pigs. J. Appl. Genet. 46: 195-200.

Georgescu SE, Manea MA, Dinescu S and Costache M (2014). Comparative study of leptin and leptin receptor gene expression in different swine breeds. Genet. Mol. Res. 13: 7140-7148. https://doi.org/10.4238/2014.February.14.15

Gerbens F, van Erp AJM, Harders FL, Verburg FJ, et al. (1999). Effect of genetic variants of the heart fatty acidbinding protein gene on intramuscular fat and performance traits in pigs. J. Anim. Sci. 77: 846-852. https://doi. org/10.2527/1999.774846x

Goddard ME and Hayes BJ (2009). Mapping genes for complex traits in domestic animals and their use in breeding programmes. Nat. Rev. Genet. 10: 381-391. https://doi.org/10.1038/nrg2575

Gondim VS (2015). Polimorfismos nos genes MC4R, FABP1, DGAT1 e LEPR e suas associações com produtividade em matrizes suínas. Doctoral thesis. UNESP Jaboticabal.

Hayashi K, Hashimoto N, Daigen M and Ashikawa I (2004). Development of PCR-based SNP markers for rice blast resistance genes at the Piz locus. Theor. Appl. Genet. 108: 1212-1220. https://doi.org/10.1007/s00122-003-1553-0

Herrero-Medrano JM, Megens HJ, Groenen MA, Bosse M, et al. (2014). Whole-genome sequence analysis reveals differences in population management and selection of European low-input pig breeds. BMC Genomics 15: 601. https://doi.org/10.1186/1471-2164-15-601

Jokubka R, Maak S, Kerziene S and Swalve HH (2006). Association of a melanocortin 4 receptor (MC4R) polymorphism with performance traits in Lithuanian White pigs. J. Anim. Breed. Genet. 123: 17-22. https://doi.org/10.1111/j.1439$\underline{0388.2006 .00559 . x}$

Larsen NJ and Nielsen VH (1993). ApaI and CfoI polymorphisms in the porcine growth hormone gene. Anim. Genet. 24: 71. https://doi.org/10.1111/j.1365-2052.1993.tb00928.x

Lenstra JA, Groeneveld LF, Eding H, Kantanen J, et al. (2012). Molecular tools and analytical approaches for the characterization of farm animal genetic diversity. Anim. Genet. 43: 483-502. https://doi.org/10.1111/j.13652052.2011.02309.x

Li CL, Pan YC and Meng H (2006). Polymorphism of the H-ABP, MC4R and ADD1 genes in the Meishan and four other pig populations in China. S. Afr. J. Anim. Sci. 36: 1. https://doi.org/10.4314/sajas.v36i1.3976

Miller SA, Dykes DD and Polesky HF (1988). A simple salting out procedure for extracting DNA from human nucleated cells. Nucleic Acids Res. 16: 1215. https://doi.org/10.1093/nar/16.3.1215

Nonneman D and Rohrer GA (2002). Linkage mapping of porcine DGAT1 to a region of chromosome 4 that contains QTL for growth and fatness. Anim. Genet. 33: 472-473. https://doi.org/10.1046/j.1365-2052.2002.00938 5.x

Óvilo C, Fernández A, Rodríguez MC, Nieto M, et al. (2006). Association of MC4R gene variants with growth, fatness, carcass composition and meat and fat quality traits in heavy pigs. Meat Sci. 73: 42-47. https://doi.org/10.1016/j. meatsci.2005.10.016

Peripolli E, Munari DP, Silva MVGB, Lima ALF, et al. (2017). Runs of homozygosity: current knowledge and applications in livestock. Anim. Genet. 48: 255-271. https://doi.org/10.1111/age.12526

Prates EG, Nunes JT and Pereira RMA (2014). Role of lipid metabolism during cumulus-oocyte complex maturation: impact of lipid modulators to improve embryo. Mediators Inflamm. 2014 Article ID 692067, 11 pages.

Renaville B, Piasentier E, Fan B, Vitale M, et al. (2010). Candidate gene markers involved in San Daniele ham quality. Meat Sci. 85: 441-445. https://doi.org/10.1016/j.meatsci.2010.02.013

Renaville B, Prandi A, Fan B, Sepulcri A, et al. (2013). Candidate gene marker associations with fatty acid profiles in heavy pigs. Meat Sci. 93: 495-500. https://doi.org/10.1016/j.meatsci.2012.11.019

Rothschild MF (2000). Advances in pig molecular genetics, gene mapping and genomics. ITEA 96A: 349-361.

Schiavo G, Galimberti G, Calò DG, Samorè AB, et al. (2016). Twenty years of artificial directional selection have shaped

Genetics and Molecular Research 16 (3): gmr16039759 
the genome of the Italian Large White pig breed. Anim. Genet. 47: 181-191. https://doi.org/10.1111/age.12392

Stachowiak M, Nowacka-Woszuk J, Szydlowski M and Switonski M (2013). The ACACA and SREBF1 genes are promising markers for pig carcass and performance traits, but not for fatty acid content in the longissimus dorsi muscle and adipose tissue. Meat Sci. 95: 64-71. https://doi.org/10.1016/j.meatsci.2013.04.021

Tyra M and Ropka-MoliK K (2011). Effect of the FABP3 and LEPR gene polymorphisms and expression levels on intramuscular fat (IMF) content and fat cover degree in pigs. Livest. Sci. 142: 114-120. https://doi.org/10.1016/j. $\underline{\text { livsci.2011.07.003 }}$

Tyra M, Ropka-Molik K, Eckert R, Piórkowska K, et al. (2011). H-FABP and LEPR gene expression profile in skeletal muscles and liver during ontogenesis in various breeds of pigs. Domest. Anim. Endocrinol. 40: 147-154. https://doi. org/10.1016/j.domaniend.2010.10.001

Vize PD and Wells JRE (1987). Isolation and characterization of the porcine growth hormone gene. Gene 55: 339-344. https://doi.org/10.1016/0378-1119(87)90294-0

Wylie ARG (2011). Leptin in farm animals: where are we and where can we go? Animal 5: 246-267. https://doi.org/10.1017/ $\underline{\mathrm{S} 1751731110001540}$

Zang L, Wang Y, Sun B, Zhang X, et al. (2016). Identification of a 13 bp indel polymorphism in the 3'-UTR of DGAT2 gene associated with back fat thickness and lean percentage in pigs. Gene 576: 729-733. https://doi.org/10.1016/j. gene.2015.09.047

Genetics and Molecular Research 16 (3): gmr16039759 